\title{
THE ANALYSIS OF MANDIBULAR TRABECULAE ALVEOLAR PROCESS ON POST-MENOPAUSAL WOMEN THROUGH PANORAMIC RADIOGRAPH
}

\author{
(ANALISIS TRABEKULA PROSESUS ALVEOLAR MANDIBULA PADA PEREMPUAN PASCA \\ MENOPAUSE MENGGUNAKAN RADIOGRAF PANORAMIK)
}

\author{
Azhari \\ Deparment of Radiology, Faculty of Medicine, \\ Universitas Padjadjaran \\ J1 Sekeloa selatan no 1, Dipati ukur Bandung,Indonesia \\ Email:azhari@fkg.unpad.ac.id
}

\begin{abstract}
The alveolar process is the most supporting tooth containing trabeculae and has the highest metabolic rate in the mandibular body of post-menopausal women. The decreasing in estrogens level on post-menopausal women results a faster reaction than men for 2-3 times. This research aims to determine the bone quality based on trabeculae alveolar process analysis using panoramic radiographs. The research methodology was to conduct 67 samples of panoramic radiographs from RSGM Unpad. This research applied observational methodology by taking cross-sectional data using secondary data on three groups of bone quality based on measurement using DEXA t-score (normal, osteopenia and osteoporosis). The panoramic radiograph data processing was conducted with Image $\mathrm{J}$ software by separating the background and foreground (trabeculae). A focus of 30x30 mm ROI in the alveolar distal portion of the left and right mandibular second premolar teeth, and calculation of trabecular area. Result: average of normal trabecular area: $82.35 \%$, osteopenia: $73.9 \%$ and osteoporosis: $68.7 \%$ respectively. The difference between normal and osteoporosis was discovered, but no difference was found between normal and osteopenia with $p<0.05$. This research concludes that the region of interest trabecular of alveolar process with panoramic radiograph can be used to detect osteoporosis on postmenopausal women.
\end{abstract}

Keywords: trabeculae alveolar, osteoporosis, panoramic radiograph

\begin{abstract}
Abstrak
Prosesus alveolar merupakan pendukung gigi paling banyak mengandung trabekula dan, mempunyai tingkat metabolism paling tinggi di bodi mandibular perempuan pasca menopause. Penurunan estrogen pada perempuan pasca menopause memberikan reaksi 2-3 kali lebih cepat dari pada laki-laki. Tujuan penelitian untuk menentukan kualitas tulang berdasarkan analisis trabekula prosesus alveolaris menggunakan radiograf panoramik. Metode penelitian dilakukan terhadap 67 sampel radiografi panoramik dari RSGM Unpad. Penelitian ini menggunakan metode observasional dengan pengambilan data secara crosssectional menggunakan data sekunder pada tiga kelompok kualitas tulang berdasarkan pengukuran yang menggunakan t-score DEXA (normal, osteopenia dan osteoporosis). Proses pengolahan data radiograf panoramik menggunakan software Image $J$ dengan memisahkan bagian latar (background) dan trabekula (forground). ROI 30x30 mm pada alveolar bagian distal gigi premolar kedua mandibula kiri dan kanan, dan hitungan luas area trabekula. Hasil: rata-rata luas area trabekula normal rata-rata: $82,35 \%$, osteopenia: $73,9 \%$ dan osteoporosis: $68,7 \%$. Terdapat perbedaan antara normal dan osteoporosis dan tidak terdapat perbedaan antara normal dan osteopenia $\mathrm{p}<0,05$. Region of interest prosesus alveolar trabekula dengan radiografi panoramik dapat digunakan untuk mendeteksi osteoporosis perempuan pascamenopause.
\end{abstract}

Kata kunci: trabekula alveolar, osteoporosis, radiograf panoramic

\section{INTRODUCTION}

The incidence of Osteoporosis in post-menopausal women in Indonesia is quite large, namely $32.8 \%$ in, is ranked 3rd in Southeast Asia and is number 5 worldwide. ${ }^{1}$ Along with the increasing of life expec- 
tancy, the number of elderlies will continue to rise. Projections of 2030, the population of menopausal women will be 1.2 billion with 47 million new cases each year. $^{2}$

The decreasing of estrogens level in post-menopausal women is an issue that will hinder the growth regulator and homeostasis. The direct effect of estrogens decreasing will increase interleukin 1 (IL1), interleukin 6 (IL6), and alpha tumour necrosis factor (TNF $\alpha$ ) by monocytes. The osteoclast activity increases through the RANK receptor pathway and macrophage colony stimulating factor (M-CSF), both of which stimulate osteoclasts. A decrease in estrogens is also followed by a decrease in apoptosis in osteoclast cells, so that the resorption process occurs more frequent. The osteoclast activity by extending villi to the bone excreting proteolytic enzymes containing collagens and carbonic anhydrase II (CA II), citric acid and lactic acid. Collagenase enzyme destroys bone collagen while CA II enzyme catalyzes $\mathrm{CO}_{2}$ to be intracellular $\mathrm{H}_{2} \mathrm{CO}_{3}$. Meanwhile, the CA II enzyme also catalyzes $\mathrm{H}_{2} \mathrm{CO}_{3}$ into $\mathrm{H}^{+}$and $\mathrm{HCO}_{3}$. The high levels of $\mathrm{H}^{+}$can cause dissolution of calcium ions in bone. ${ }^{3,4}$ Reduction in bone quality can have implications for periodontal tissues, causing tooth loss, BMD reduction, alveolar cervical resorption and cortical thinning which can be reflected on panoramic radiographs. ${ }^{7}$

Maxillofacial panoramic radiography can be seen without left and right superimposed side. So that this technique, even within limits, will still be widely used in the world and also within Indonesian dentists before dental treatment. Panoramic radiograph data can be utilized to predict bone quality by observing its micro and macrostructure. Recently, the standard used to indicate the bone quality is using Dual Exposures X ray Absorpsimetry (DEXA). ${ }^{\top}$ The basic principle is similar, which is using the radiograph but DEXA is using dual energy. DEXA equipment is still rare and only found in large hospitals and is expensive to use. Patients are rarely performing bone quality checking. Hence, DEXA examination is performed after a fracture occurs. This of course, will consume much money for the patients. The efforts to find new standard continue to be carried out in line with the progress of radiographic techniques with digital systems. Panoramic radiographs are widely used recently because they are easy to obtain, affordable, low doses, and widely used by dentists. Based on the results of several studies, it is women that frequently visited the dentist. Menopausal women have osteoporosis problems three times greater than men due to the decreased estrogens, so early bone quality determination is needed and becomes important. It is important to determine bone quality on early stage, and examination based on panoramic radiographs is very possible as early detection. The earliest stage to determine the bone quality based on mandibular cortical is pretty welldeveloped in the world.

In Europe, researchers like Klimetti et al already have a cortical standard based on European standard, while in Asia was developed by Taguchi et al. ${ }^{8}$ In Indonesia, researches are still conducted. With the increase of technological developments in digital and software, researchers shifted and argued that determining bone quality based on cortical can be relatively slow that it less accurate compares to trabecular. Trabecular metabolism is up to 8 times higher than cortical. ${ }^{9}$ The basic standards of DEXA trabeculae are becoming ROI on lumbal. The problems that arise are difficulties in determining or observing ROI trabecular that is spared from local effects such as one-sided mastication and infection. The choice of process alveolar of trabeculae as ROI is caused by its highest metabolic rate in mandibular and is more homogeneous than maxillary. ${ }^{9}$ The aim of this research is to determine bone quality in post-menopausal women using extensive trabecular alveolar process on digital panoramic radiographs.

\section{MATERIALS AND METHODS}

This is a cross-sectional research, conducted by using secondary data with inclusion criteria: postmenopausal women with age range of 50 to 80 years, who already have Panoramic and DEXA Radiographic Data at RSGM FKG Universitas Padjadjaran Bandung. DEXA data which is in the form of t-score data is used as a basis for the Bone Mineral Density (BMD) classification (t-score >-1 normal, t-score <2.5 osteoporosis and between -1 and -2.5 osteopenia) will be used as the gold standard.

The research sample was taken based on the patient's arrival (consecutive sampling) which was based on the order of visit until the minimum sample number was fulfilled. The equipments which is was Computer Unit with the specific Intel Pentium Dual core $2 \mathrm{GHz}$ processor, Samsung 4GB screen monitor, Image J Program, digital panoramic X-ray (Vatex Korintificea, $12 \mathrm{~mA}$ and 70 and $80 \mathrm{kVp}$, Screen speed 200).

Alveolar trabeculae were analyzed for the distal part of the second premolar tooth, the central Region of Interest (ROI) in the middle of the height of the root, which is from Cemento Enamel Junction and worn teeth. 


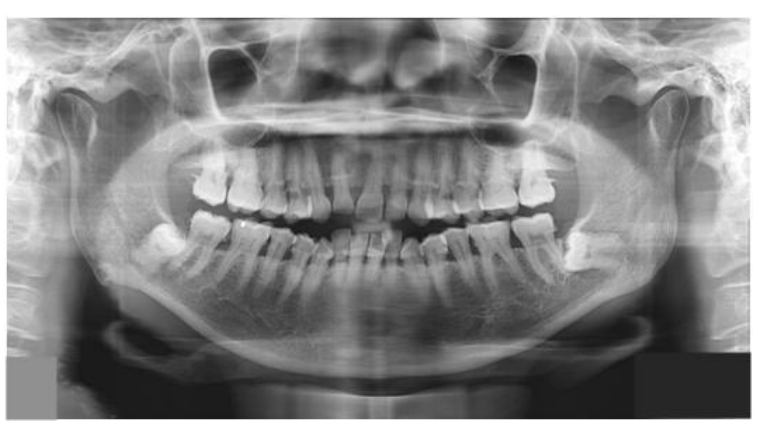

Figure 1. The picture of panoramic radiograph

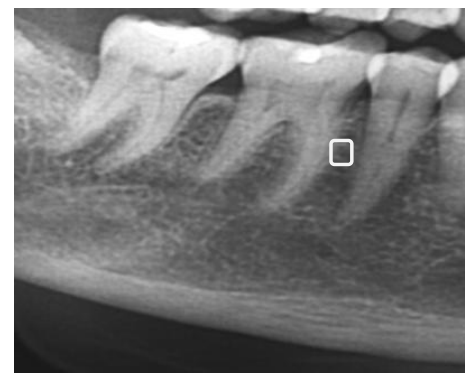

Figure 2. The box with size of 30x30 of premolar distal was made from the centre of ROI

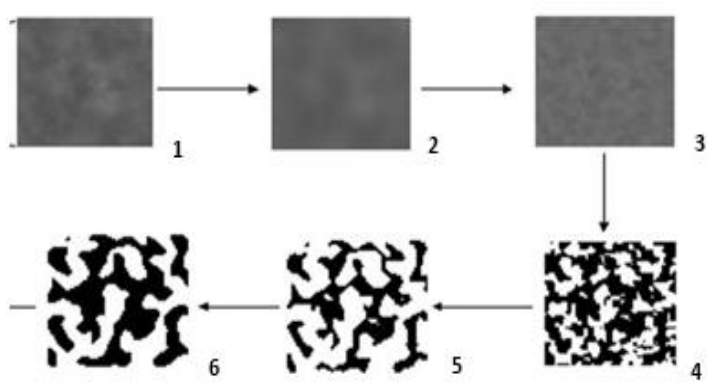

Figure 3. The Processing film by Image J

It was carried out on normal panoramic radiographs of trabeculae, osteopenia and osteoporosis based on DEXA analysis. The radiograph processing is using the Image J Program for trabecular pattern from micro analysis structure. Digital radiographs are opened with a region of interest (30x30 pixels) taken from the alveolar, then the image was cropped and saved in Tiff format (original image), enhancement with high pass filtering through (original-low pass filtering image) using a Gaussian filter which was designed to release the huge number of variations of brightness caused by differences in object thickness and overlap with soft tissue. Then, the blurring (low pass filter) was performed using a twolevel Gaussian filter (sigma 35 pixels, 33x33 kernel size). This stage releases scales of all fine and me- dium scale and the one which was left is having the large-scale density.

The original picture minus the blur image produces an image that has a brightness variation by showing trabeculae and marrow areas. Then, binarization is performed with thresholding (128 pixels). This will display a black image (background) and white (foreground). The binary image is eroded and dilated three times to eliminate noise. ${ }^{10}$

\section{RESULTS}

The Research on trabeculae on panoramic radiographs to diagnose osteoporosis on panoramic radiographs of post-menopausal women has been performed on 64 panoramic radiographs.

Table 1. The average of trabeculae area on normal bone quality group

\begin{tabular}{ccc}
\hline No & $t$-Score & \multicolumn{2}{c}{ Trabecular area (\%) } \\
\cline { 2 - 3 } & Right & Left \\
\hline Average & 84,4 & 80,3 \\
& & \\
\hline
\end{tabular}

The average area of the left and right trabeculae in the normal group is $82.35 \%$.

Table 2. The average of trabeculae area on Osteoporosis group

\begin{tabular}{|c|c|c|c|}
\hline \multirow[t]{2}{*}{ No } & \multirow[t]{2}{*}{$t$-Score } & \multicolumn{2}{|c|}{ Trabecular area $(\%)$} \\
\hline & & Right & Right \\
\hline Average & & 66,3 & 71,1 \\
\hline
\end{tabular}

From the calculation results, the normal left and right averages are $82.35 \%$, while the left and right averages for osteoporosis are $68.70 \%$. The homogeneity test showed the $\mathrm{f}$ value calculated is at 0.025 and the $\mathrm{p}$ value (sig) is 0.873 , which is greater than 0.05 . Therefore, Ho is accepted because the above group variance was homogeneous.

The results of different tests between normal and osteoporosis group showed the $\mathrm{p}$ value (sig) of 0.00 and less than 0.05 , which indicates that Ho was rejected. Therefore, the significant differences between normal and osteoporosis groups is revealed with $\mathrm{p}$ $<0.05$. 
Table 3. The average of trabeculae area on Osteopenia group

\begin{tabular}{|c|c|c|c|}
\hline \multirow[t]{2}{*}{ No } & \multirow[t]{2}{*}{$t$-Score } & \multicolumn{2}{|c|}{ Trabecular area $(\%)$} \\
\hline & & Right & Left \\
\hline Average & & 74,07 & $\mathbf{7 3 , 7 3}$ \\
\hline
\end{tabular}

The average area of the trabecular area is $73.9 \%$, while for the average different test for Two Independent Samples; the p-value (sig) was 0.882. Since the value is greater than 0.05 , it can be concluded that there is no difference in trabecular area between the normal group and osteopenia. The results of different tests between the normal group and osteopenia did not differ significantly.

\section{DISCUSSION}

Several efforts have conducted to make detection of osteoporosis be more detectable. The use of panoramic radiographs with various methods has been developed because the use of Dual exposure Xray Absorpsimetry (DEXA) as a standard is found difficult to be conducted especially due to the limitations of equipments, rareness and expensiveness. The bone quality analysis using panoramic radiographs continues to be developed primarily based on cortical radio morphology. Several radio morphology indexes have been developed with various methods such as the Mandibular Cortical Index (MCI), Panoramic Mental Index (PMI), Gonial Index (GI), ante gonial Index (AI), Mental Index (MI) and the ratio of alveolar bone height and mandibular basal bone. ${ }^{11}$

Klemetti, Kolmokow, Taguchi, and Bollen et al, ${ }^{12}$ stated that MCI is the best in terms of its well correlation with the DEXA Lumbal. Whereas Mohajery and Brooks, ${ }^{13}$ did not find a relationship between cortical thinning at the mandibular angle, sinus base and lamina dura which correlated with DEXA Lum-bal. Likewise with Balciconyte et $a l^{14}$ who revealed that there was no DEXA lumbal relation between alveolar body height and mandibular bone basal. Moreover, Cakur et al. ${ }^{11}$ showed no correlation between DEXA mandibular bone density and DEXA lumbal bone. This disparity in results is caused by differences in methods and research samples. Other researchers found that cortical is less sensitive than trabeculae, because the thinning changes appear after 5 years, so they are not sensitive to be used as a basis for determining bone quality. Then, the development of trabecular bone-based research happened and was carried out using pa- noramic radiographs, CBCT, ultrasound, Quantitative Computed Tomography (QCT), and micro CT.

Taguchi et $a l^{8}$ discovered a relationship between trabeculae and mandibulae through QCT with DE$\mathrm{XA}$ lumbal bone. This is accordance to Amer et $a l^{10}$ who said that in various places on the mandibular can be made as ROI, where there is a correlation between the location of Region of Interest (ROI) angulus, ROI dimental foramen and diapex trabeculae with an incisive bottom. Watanabe et $a l^{15}$ stated that ROI trabeculae, mental foramen can be used for bone quality analysis. The bone structure change in post-menopausal women occurs in all bones but the severity is different and is related to age.

This research was using panoramic radiographs and ROI on the trabeculae, in the middle of the alveolar process. The results showed that the normal and osteoporosis groups had significant differences with $\mathrm{p}<0.05$. The research in mice revealed the change in the decrease of bone mass in the inter radicular septum alveolar for the first molar, after one month of ovariectomy (decreased estrogen).$^{16}$ Jie Yang et al. ${ }^{17}$ stated that there was trabecular thinning in mice that had ovariectomy and decreased in trabecular area. The first change occurred on trabeculae which was formed enchondrally at the end of long bones. The decrease in trabeculae is closely related to chewing power, because studies with onesided tooth extraction in mice have differences in trabecular density and do not occur in cortical. ${ }^{18,19}$

Descriptively, the results of the right trabecular density showed a greater value than the left one. This might be due to the one-sided mastication pattern. To eliminate these factors, the average left and right values were taken. In contrast to experimental animals, mice and monkeys have different patterns of mastication with humans. Trabecular based studies on monkey jaws have a higher sensitivity and accuracy than cortical based. ${ }^{20,21}$

The different test results for normal group and osteopenia indicated no difference. This situation can be identified from two aspects, namely the factor of panoramic radiographs and anatomical factors. Inconsistency in osteopenia group values is due to the fewer amounts of changes which cannot be detected by panoramic radiographs based on limited resolution, lots of noise and superimpose, so that it is unable to detect the differences radio graphically. Several weaknesses in research might occur because many other factors that are difficult to control which can affect the extent of trabeculae, such as uncontrollable anatomical factors, for example; one- 
sided mastication, chewing load, nutrition, missing teeth, exercise and age range, body mass index and socio-economic status.

Conclusion: the area of the alveolar region of the trabeculae using the panoramic radiographs can be used as a basis for detecting bone quality in post-

\section{REFERENCES}

1. Azhari, Suprianto, E Juliastuti, Diputra Y, Agus Arifin A Z. Panoramic matrix method radiograph image using cooccurrence gray level matrix (GLCM) for early detection of osteoporosis in mandibular bone. Majalah Kedokteran Bandung (MKB) 2014; 46(4): 203-208.

2. Stauber M and Muller R. Age related changes in trabecular bone microstructure: global and local morphometry. Osteoporosis Int 2006; 17(4): 616-26.

3. Gulsahi A, Yuzugullu B, Imirzalioglu P, Genc Y. Assessment of panoramic radiomorphometric indices in Turkish patients of different age groups, gender and dental status. Dentomaxillofacial Radiol 2008; 37(5):288-292.

4. Galal N, El Beialy W, Deyama Y, Yoshimura Y, Yoshikawa T, Suzuki K, et al. Effect of estrogen resorption and inflammation in the temporomandibular joint cellular elements. Int J Mol Med 2008; 21(6): 785-90

5. Henry CH, Tull GT, Whittum-Hudson JA, Wolford LM. Analysis of estrogen binding sites of the posterior ligament of the human TMJ. Oral Surg Oral Med Oral Pathol Radiol Endod 2008; 105(6): 698701

6. Hildebolt CF. Osteoporosis and oral bone loss. Dentomaxillofac Radiol 2008; 26(1): 3- 15.

7. Amer ME, Heo MS, Brooks SL, Benavides E, Anatomical variations of trabecular bone structure in intraoral radiographs using fractal and particle count analyses. Imaging Sci Dent 2012; 42(1): 5-12.

8. Taguchi A, Ohtsuka M, Tsuda M. Risk of vertebral osteoporosis in post menopausal women with alterations of the mandible. Dentomaxillofac Radiol 2007; 36(3): 143-8.

9. White SC, Atchison KA, Gornbein JA, Nattiv A, Paganini-Hill A, Service SK, et al. Change in trabecular pattern of and hip fracture rate in elderly women. Dentomaxillofac Radiol 2014; 34(3):168 -174

10. Huh KH, Baik JS, Yi WJ, Heo MS, Lee SS, Choi $\mathrm{SC}$, et al. Fractal analisis of mandibular trabecular bone optimal tile sizes for the tile counting method. Imaging Sci Dent 2011; 41(2): 71- 8

11. Cakur B, Dagistan S, Sahin A, Harorli A, Yilmaz A. Reability of mandibular cortical index and mandibular bone mineral density in detection osteoporotic menopausal women by grouping into two normal groups (normal + osteopenia) and osteoporosis.

Suggestion: further research is needed by controlling the confounding variables such as mastication patterns, number of missing teeth, socio-economic status and using minimal superimpose and low radiation radiographs.

women. Dentomaxillofac Radiol 2008; 38 (5): 255261.

12. Bollen AM, Taguchi A, Hujoel PP, Hollender LG. Case control study on self reported osteoporosis fracture and mandibular cortical bone. Oral Surg Oral path Oral Radiol Endo 2000; 90(4): 518-524.

13. Brooks SL, Mohajery M. Oral radiograph in the detection of early sign of osteoporosis. Oral Surg Oral Med Oral Path 1992; 73(1): 112-7

14. Balcikonyte E, Balciuniene I, Alekna V. Bone mineral Density and Radiographic Mandibular body height. Stomalogija 2003; 5: 137-140.

15. Watanabe PCA, Issa JPM, de Oliviera TM, Monteiro SAC, Iyomasa MM, Regalo SCH, et al. Morphology study of the mandibular trabecular bone in Panoramic radiograph. Int J Morphol 2007; 25(4): 875-80

16. Stauber M, Muller R. Age related changes in trabecular bone microstructure: global and local morphometry. Osteoporos Int 2006; 17(4): 616-26

17. Yang J, Pham SM and Crabbe DL. Effects of oestrogen deficiency on rat mandibular and tibial microarchitecture. J Dentomaxillofac Radiol 2003; 32(4): 247-51.

18. Gulsahi A, Yuzugullu B, Imirzalioglu P, Genc Y. Assessment of panoramic radiometric indices in Turkish patients of different age groups, gender and dental status. Dentomaxillofac Radiol, 2008; 37(5): 288-92

19. Asai H, Kosai Y, MatsumotoY, Kamamata Y, Kumasaka S, Sakurai T, Kashima I. Radiological morphometric analysis mandibular bone structure after ovariectomy in mature cynomolgus monkey. Oral Sci Int 2005; 2(1): 54-63.

20. Gungor $\mathrm{K}$ et al. The precision of the panoramic radiomorphometric indices in Turkish patients of different age groups, gender and dental status. J Dentomaxillofacial Radiology., 2006; 35 :442-446.

21. Genant HK, Block JE, Steiger P, Glueer CC, Smith R. Quantitative computed tomography in assessment of osteoporosis. J Semin Nucl Med 1987: 17(4): 31633

22. Choël L, Duboeuf F, Bourgeois D, Briguet A, Lissac M. Trabecular alveolar bone in human mandible: a dual energy x-ray absorptiometry study. Oral surg Oral path Oral Med Oral Radiol Endod 2003; 95(3): 364- 70. 